\title{
The Official Secrets Act 1989: the Right Balance?
}

\author{
I. N. Stevens*
}

The celebration of the centenary of a controversial Act of Parliament by means of the enactment of yet another, sharing the same title and basic purpose, must be something of a rarity. Yet this is precisely what has occurred this year, with the granting of the Royal Assent to the Official Secrets Act 1989 on May 11. The commencement date has yet to be announced at the time of writing (September, 1989).

The new Act has not closed the circle, however: far from it, in fact. Whilst, prior to the Official Secrets Act 1889, no criminal sanctions applied to the unauthorised disclosures of "official" information, not only has the 1989 Act retained the use of such sanctions, it has also provided for offences of strict liability in connection with some kinds of disclosures. Whether criminal sanctions are necessary, or even desirable, in connection with disclosures which fall short of espionage, or are in no way of assistance to an enemy or potential enemy, is itself a highly vexed question. This article does not address that issue as such, but seeks to assess the new Act mainly in terms of the objectives which, according to the Government, it sought to achieve. In this context, the necessity of resorting to criminal sanctions in some cases has been more-or-less assumed: the question, therefore, is: will these be directed towards the appropriate cases? In a world in which "freedom of information", "the public interest" and "open Government" are, increasingly, much-used (some would say over-used) phrases, it is essential that a piece of legislation that imposes, or retains, criminal sanctions in cases of disclosures of even delicate information must strike the right balance. All of the above interests, as well as the occasional requirements of confidentiality, and even the risk of harm to the public service or other branches of Governmental activities, must be weighed in the balance if one is to answer that question satisfactorily. This, the Government claims to have done. The purpose of this article is to examine that claim, against the background of a century of Official Secrecy.

\section{The growth of official secrecy and background to the Act}

It is strange, perhaps, to contemplate that the first Official Secrets Act was passed in 1889. Prior to that date, no criminal sanctions existed for preventing

"Of The School of Law, University of Buckingham. 
cases of "breach of official trust"1 as such. Instead, the authorities had to rely on mainstream criminal law, such as the Larceny Act 1861. The best known example of a case which highlighted this gap in the law - indeed, the case which is commonly thought to have precipitated the 1889 Act - was that of Charles Marvin, in 1878. Marvin was a temporary clerk at the Foreign Office, who supplemented what he described as a "miserable" wage by writing articles for The Globe. One such article contained the gist of a secret treaty, to which Marvin had access in the course of his employment, and which (being endowed with a prodigious memory) he was able to recall and duplicate at The Globe's offices. Later, he made a copy of the entire treaty, taking the precaution of using his own notepaper, and this, too, was published.

Marvin was identified as the source of what was a politically embarrassing leak. The case against him was dismissed, however, since he had not actually removed the document, nor even stolen the paper used to transcribe it.

In 1888, a "Breach of Official Trust" Bill was introduced in the Lords. On receiving the Royal Assent, it became the Official Secrets Act, 1889. Like its successor Act of 1911, this Act aroused controversy, not least in the manner in which it underwent its Commons' stages. Like the 1911 Act, it sought to address two distinct problems: espionage (in Section 1); and unauthorised disclosures of official information (in Section 2). In both cases, however, the 1889 Act was somewhat narrower in scope than that of 1911; section 2, in particular, since it applied criminal sanctions to unauthorised disclosures by Crown servants or contractors only. Furthermore, such disclosures were unlawful only when made "to any person to whom [the information] ought not, in the interest of the State or otherwise in the public interest, to be communicated ...." The Act (and particularly section 2) was not especially effective (few successful prosecutions being brought) so that, by the turn of the century, attempts to strengthen its provisions were being made.

For many years, there was a common misconception that the Official Secrets Act 1911 , passed hurriedly as it was, ${ }^{3}$ was a piece of emergency legislation, in response to the growing threat of German activities including espionage. The 1909 report of a Defence Committee, however, suggests that not only the contents of the new Bill (and especially section 2), but even the manner of its introduction in Parliament, had been carefully considered, and planned, well in advance of $1911^{4}$

1. The original title of the Bill.

2. This is, of course, the basis of the "public interest" defence which, particularly since the Ponting case (infra) has been so controversial, and which is conspicuously absent from the 1989 Act.

3. It underwent all its Commons stages in the afternoon of August 18; s.1 was not even debated!

4. A newspaper had published details of warships. Lamenting their inability to prosecute the newspaper (as opposed to the source, if known) under the 1889 Act, the Commirtee's report comments: "We ought to be in a position to prosecute the proprietor of the newspaper ..."; and later, "... such a Bill would excite less opposition if it were introduced by the Secretary of State for War than by the Home Secretary, and that this might be done on the plea of it being a measure of precaution of great importance in national defence". 
The 1911 Act "strengthened" the law in a number of ways. Thus (regarding Section 1) whilst the 1889 Act had been silent as to the burden of proving the required intention on the part of the accused, section 1(2) of the 1911 Act clearly relieved the prosecution of any such burden; and placed the burden of disproving such an intention on the accused. ${ }^{5}$ Moreover, the prescribed criminal intention was itself broadened to include "any purpose prejudicial to the safety or interests of the State." The range of both "prohibited places" and "prohibited conduct" were also extended, so that (for example) it became criminal merely to "approach" or be "in the neighbourhood" of a "prohibited place". (The 1889 Act had been narrower, requiring actual entry into one of the places actually itemised in the Act, or, if outside it, making a sketch or plan of such a place). Finally, the 1911 Act "upgraded" section 1 offences to felonies, punishable by penal servitude ${ }^{7}$ for between three and seven years.

The extended scope of section 1 can be seen in the case of Chandler v. D.P.P., ${ }^{8}$ which established that the provisions of section 1 could be used in cases of sabotage, even where no damage was done, and this despite the margin heading "Penalties for Spying". In the Chandler case, some C.N.D. protestors sought temporarily to incapacitate Wethersfield airbase (where NATO command aircraft were based) by means of a peaceful "sit-down" type protest. Their long-term purpose, they maintained throughout, was nuclear disarmament. This, they argued, was positively beneficial to society, and could hardly, therefore, be described as "prejudicial to the safety or interests of the State."

They were nevertheless convicted, and appealed (eventually) to the House of Lords, who upheld the convictions. In his judgment, Lord Reid stated: “ ... 'State' is not an easy word. It does not mean the Government or executive ... perhaps the country, or the realm are as good synonyms as one can find ...". Later he added, ${ }^{10}$ arguably perpetuating - albeit inadvertently - the misconception concerning the Act's genesis, “... The 1911 Act was passed at a time of grave misgivings about the German menace, and it would be surprising and hardly

5. It stated: ". . . if any [information] relating to ... any prohibited place within the meaning of this Act ... is made, obtained or communicated by a person other than a person acting under lawful authority it shall be deemed to have been made ... for a purpose prejudicial to the safety or interests of the State unless the contrary is proved" ("a purpose prejudicial to the safety or interests of the state" being the intention prescribed by the Act).

6. "Prohibited places" now included, as well as arsenals, dockyards, camps and the like, "any work of defence, arsenal dockyard, camp, ship, telegraph or signal station belonging to His Majesty", and any other place, whether belonging to His Majesty or not where ships, arms or other "defence" materials were built, stored, made or repaired. Furthermore, the Act empowered the Secretary of State to "declare" such things as railways, roads or other means of communication, or any place "belonging to His Majesty" to be a "prohibited place" for the purposes of the Act: Official Secrets Act 1911, s.3.

7. 'Till its abolition in 1948: Criminal Justice Act 1948, S.1. The actual term was increased once more in 1920 to a maximum of fourteen years: Official Secrets Act 1920, s.8(1).(The distinction between felonies and misdemeanors itself was, of course, abolished in 1967: Criminal Law Act 1967, s.1.)
8. [1964] A.C. 763.
9. Supra.
10. At p.701. 
credible that the Parliament of that date intended that a person who deliberately interfered with vital dispositions of the armed forces should be entitled to submit to a jury that Government policy was wrong and that what he did was really in the interests of the State." At all events, the case seems to have decided that "interests of the State" could not be divorced from the policy of the Government of the day, and that, for practical purposes, the two are synonymous.

Apart from the precise legal issues involved, the decision was not a popular one, and prompted the Attorney-General ${ }^{11}$ to make a statement to the effect that prosecutions under section 1 should really be confined, as far as possible, to cases of espionage or (at least) clear cases of sabotage. The section was not, for instance, used against the Greenham Common women, though several were prosecuted for (inter alia) criminal damage and offences of obstruction. The Attorney's statement was taxed, however, in the notorious $A . B . C$. trial in 1978, ${ }^{12}$ when section 1 charges were again brought. Whilst acknowledging that section 1 extended to cases of sabotage, as well as espionage, the trial judge, Mars-Jones $\mathrm{J}$, indicated that, in cases of this kind, involving "investigative journalism", such charges were "oppressive". The section 1 charges were quietly dropped, though the defendants were convicted of various charges under section 2 . Less controversially, section 1 has been used in the various celebrated "spy-trials", such as those of George Blake in 1960, and of Michael Bettany and Geoffrey Prime in the early 1980s.

Since it has been untouched by the 1989 Act, section 1 remains important. It is to be hoped, however, that the Government's failure to reform it does not indicate a willingness for prosecutions under section 1 to be brought in cases like Chandler and the $A . B . C$. case in future, particularly since recent legislation may well prove (at least in cases like Chandler) adequate to deal with any problems which might otherwise arise. $^{13}$

To turn now to section 2 of the 1911 Act. Until its repeal in May 1989, it remained one of the most controversial of all statutory provisions. Even some judges have roundly condemned it; one, in 1970, suggesting it should be "pensioned off'. ${ }^{13}$ Its reform, however, has been problematical. Indeed, even when it came about, it took an entire Act of sixteen sections to repeal it!

The main problem with section 2 - though some would arguably see it as a strength - lay in a single phrase: 'catch-all'. As it stood, section 2 was capable of making virtually any unauthorised disclosure of any "official" information whatsoever, by any person whatsoever, a criminal offence. As well as extending criminal sanctions to persons other than crown servants and contractors, section 2 made the mere receipt of "official" information an offence, unless this occurred

11. Whose consent is necessary for any prosecution under the Act: Official Secrets Act 1911, s.8. 12. [1978] Crim. L.R. and named because of the defendant's surnames: Aubrey, Berry and Campbell. The first and last of these were journalists.

13. See, e.g., the Public Order Act 1986, S.38.

14. Per Caulfield $\mathrm{J}$, in connection with the prosecution of Jonathan Aitken (then a parliamentary candidate and journalist), with others, over the "Nigerian Report" (as Franks puts it). 
"contrary to the desire" of the receiver. It also narrowed the scope of the "public interest" defence, ${ }^{15}$ and created (as amended) ${ }^{16}$ a further offence, namely failure "to take reasonable care" of "official" information or documents. The history of section 2 is a chequered one. It has been used in connection with many different kinds of unauthorised disclosures, some of which would seem to pose little or no threat to the public interest, or state security. In 1926, for instance, in the first case where a section 2 prosecution was brought in connection with "journalistic" activities, the retired Governor of Pentonville Prison was convicted after he had written an article, published in the Evening News, and entitled "What Bywaters told me". The article revealed statements made by a convicted murderer, Frederick Bywaters, on the eve of his execution. The defendant's claim that these revelations had not been contrary to the public interest did not avail him. He was fined $£ 250$ and ordered to pay costs. The editors of the newspaper were not prosecuted. The first prosecution of the author of an article based on information supplied to him by an official in contravention of the Act was not brought until 1963. Other cases of this kind included those of Jonathan Aitken (and the Editor of the Sunday Telegraph) in 1970, and the A.B.C. defendants in 1978. Many prosecutions have been brought against civil servants (in recent years, most notably Sarah Tisdall in 1984, and Clive Ponting in 1985) ${ }^{17}$ and other officials, including policemen and ex-policemen, Post Office employees, and even a clerk in the Probate Office, who "leaked", prior to its official release, information concerning wills.

Whilst the statistics are incomplete, the following figures ${ }^{18}$ based on Home Office ones, are fairly reliable as to section 2 prosecutions. In the period 1945-1955, eleven prosecutions were brought, all but one being successful. In the period 1955-1985, fifty-one individuals and one company were prosecuted, resulting in thirty-six convictions. In four cases charges were withdrawn.

\section{The reform of section 2}

There have been, over the years, several attempts at the reform of section 2 . The first significant proposal was made in 1965, when JUSTICE (the British 'branch' of the International Commission of Jurists) suggested limiting the scope of section 2 so that disclosures should be unlawful only if they threatened the national interest, or were made in breach of an undertaking of confidentiality. ${ }^{19}$ In 1968 , a committee investigating the Civil Service ${ }^{20}$ reported in general terms to

15. This, in time, received an extremely restricted interpretation by the courts: see, e.g., $R$. v. Ponting [1985] Crim. L.R. 318 .

16. Official Secrets Act 1920, s.9.

17. See, infra.

18. Based on Home Office figures, as supplied (inter alia) to the Franks Committee.

19. In fact, a reforming measure was taken in 1939 , when the extensive powers of interrogation (placing a duty on "every person" to give "any information" relating to an offence under the Act and, if required, attend at a police station) created by the Official Secrets Act 1920, were limited to section 1 offences: Official Secrets Act 1939. This did not, of course, affect s.2. as such.

20. The Civil Service Cmnd. 3638 (1968) (The Fulton Report). 
the effect that administration was "surrounded by too much secrecy", with the result that the Wilson government published a White Paper, entitled "Information and the Public Interest", the following year. ${ }^{21}$ This contained proposals for a degree of "freedom of information". It did not, however, seek to dismantle, or otherwise radically reform section 2 .

The first major proposal to do that came from the Franks Committee, which reported in $1972,{ }^{22}$ having taken evidence from some 114 persons and bodies, including many representatives of the press, broadcasting and the Law, as well as Government Departments. Its proposals were particularly significant because they formed (in part, at least) the basis of subsequent recommendations, ${ }^{23}$ as well as a Government Bill in 1979, and were certainly carefully considered by the Government in reaching its most recent recommendations (culminating, of course, in the Official Secrets Act, 1989). The essence of Franks' proposals was that section 2 should be repealed and replaced by narrower and more specific provisions, ${ }^{24}$ the effect of which would have been to apply criminal sanctions to disclosures of specified types of information only: namely, those relating to defence and internal security; foreign relations; currency; maintenance of law and order; and information given by private individuals in confidence. In relation to the first three of these, Franks proposed that the Whitehall system of classification of information should be adopted, so that a prosecution should only proceed if a Minister were to certify that the information was "secret", and that its unauthorised disclosure would cause serious injury to the interests of the nation. This requirement Franks described as the "touchstone" of his proposals. It was also suggested that sanctions should be limited to specified classes of persons, in that the "primary duty" would have fallen on to identified classes of persons, including Ministers, Civil Servants, members of the Armed Forces, the Atomic Energy Authority and Post Office, civilian personnel in the above, and former members of any of the above classes. Other persons would be guilty of an offence only if they communicated information, contrary to the proposed Act, which they knew or had reason to believe had been given to them in contravention of the Act. Mere receipt of official information should cease to be an offence.

\section{The Official Secrets Act 1989}

The White Paper of 1988 pointed out that "The recommendations of the Franks Committee have naturally dominated discussion of this issue since they were published in 1972, and have remained a necessary and valuable reference point for the Government's present consideration of the reform of section 2."25

\section{Cmnd. 4089 (1969).}

22. Report of the Departmental Committee on Section 2 of the Official Secrets Aat 1911, Cmnd. 5104 (1972). 23. See: Home Office Reform of Section 2 of the Official Secrets Act, 1911 (Commons Paper 7285, 1978); Green Paper Open Government (Cmnd. 7520, 1979).

24. Which, Franks proposed, should take the form of an "Official Information Act".

25. Cmnd. 408 (1988), at p.5. 
Unsurprisingly, therefore, the Official Secrets Act 1989 follows the Franks model in what are, perhaps, its most important particulars. Thus, the categories of information covered by the new legislation are limited, though they are not precisely the same categories as those proposed by Franks. They are information relating to: security and intelligence (S.1); defence (S.2) and international relations (S.3); information which might result or assist in the commission of an offence, or escape from custody, or impede the apprehension or detection of offences or which concerns interceptions made lawfully under the Interception of Communication Act 1985 or Security Services Act 1989 (S.4); and information relating to security or intelligence, defence, or international relations, which has been communicated in confidence to another state or to an international organisation (S.6). The Act also incorporates something very like the Franks "touchstone", in that, with some significant exceptions, unauthorised disclosures are criminal only if some harm results, or is likely to result. The Government did not, however, adopt Franks' proposed system of Ministerial certification, preferring instead to define the required harm in connection with each category of information. Thus, for instance, damage to the capability of the armed forces to carry out their task, or the risk of loss of life or injury to servicemen, or the endangering of U.K. interests abroad, indicate the kind and degree of harm required under section 2 .

The exceptions to the above arise under sections 1 and 4 . Since unlawful disclosures under section 4 , by their nature, tend to produce obvious harm (such as the commission of an offence), no additional test of harm was felt necessary. Section 1(1), on the other hand, singles out members or ex-members of the security and intelligence services and "notified" persons ${ }^{26}$ for special treatment, since unauthorised disclosure by them of any information relating to security or intelligence obtained by virtue of their work is an absolute offence. In cases of such disclosures by Crown servants and contractors a modified test of harm applies, in that a disclosure is damaging if it either causes (or is likely to cause) damage to the work of the security and intelligence services or is of information which falls within a class or description of information, documents or articles, the unauthorised disclosure of which would be likely to cause such damage. One reason, advanced by the White Paper, for drawing this distinction was that, due to the sensitivity of security and intelligence matters, the requirement that 'harm' be established in connection with a disclosure by a member or ex-member might entail the bringing of evidence which involves a disclosure at least as damaging as that which is the subject of the prosecution. ${ }^{27}$ It is hard to resist the impression, however, that a certain degree of reaction to the "Spycatcher" revelations by ex-MI5 officer Peter Wright is here involved.

26. A person may be "notified by a Minister that he is subject to the provision of s.1.(1) if, in the Minister's opinion, his work is such that the interests of national security require that he should be subject to s.1(1), by reason of its being connected with the security and intelligence services": s.1.(6). (Arguably, there are shades of Franks' "ministerial certification" here.)

27. Cmnd. 408, para. 29. 
Like Franks, too, the 1989 Act defines those persons subject to criminal sanctions by way of "primary" disclosures. These are Crown servants, including Ministers of the Crown, civil servants, servicemen, policemen and police force employees, as well as persons holding "prescribed" offices, ${ }^{28}$ government contractors, and former Crown servants or government contractors. A 'secondary' disclosure i.e., by a person other than a Crown Servant or government contractor, or former Crown servant or government contractor, is unlawful if it involves information disclosed without authority, or entrusted to the discloser or another in confidence, by a Crown servant or government contractor. A person making such a disclosure is guilty if he disclosed the information without authority, knowing or having reasonable cause to believe it was "protected"29 information. A special test of harm applies here, in that the disclosure must be damaging, and the person making it must have reasonable cause to believe it would be damaging. ${ }^{30}$

It is a defence for a person charged under sections 1-4 to show that he did not know, and had no reasonable cause to believe, that the information disclosed by him was "protected" or that the disclosure would be "damaging" according to the definitions given in each section. An exception, however, is made for members and ex-members of the security services. For such a defendant, the only defence arises if he did not know and had no reason to believe that the information disclosed related to security or intelligence. ${ }^{31}$

The mere receipt of official information ceases to be a criminal offence. On the other hand, the Act makes it quite clear that a disclosure is made by a Crown servant with lawful authority "if, and only if, it is made in accordance with [his] official duty" and, where a government contractor is concerned, if it is made in accordance with official authorisation, or for the purposes of his functions as a government contractor. ${ }^{32}$ Furthermore, unauthorised retention of a "protected" document is an offence. ${ }^{33}$

As with the 1911 Act, however, the consent of the Attorney-General remains a pre-requisite of any prosecution, except for one brought for a section 4 disclosure. Here, that of the D.P.P. will suffice. ${ }^{34}$ Sentences for illegal disclosures are, on indictment, a maximum of two years imprisonment, or a fine, or both, and on summary conviction, six months, or a fine, or both. Penalties for illegal retention

28. S.12. The Secretary of State may, by order, "prescribe" an office for the purposes of the Act: ss.12; 13.

29. I.e., within the categories given in ss.1-4.

30. S.5.

31. Sections 1(5); 2(3); 3(4); and 4(4). An interesting point of interpretation arises, however. Does the defence protect only the accused who knows (or suspects) neither that the information was protected, nor that its disclosure was likely to be damaging. Such an interpretation, in connection with official secrecy, seems by no means unlikely: see, e.g., R. v. Oakes [1959] 2 Q.B. 350.

32. Official Secrets Act 1989 s.7.

33. S.8.

34. $S .9(1)$ and (2). 
are three months or a fine up to level 5 (on summary conviction). ${ }^{35}$ Illegal disclosures are made arrestable offences. ${ }^{36}$

\section{The right balance?}

The question must now be addressed whether the Official Secrets Act 1989 achieves the right balance between the public's right of access to information concerning public administration, ${ }^{37}$ and the protection of that official information which, for reasons of the public interest, should be kept secret. We are not here concerned with espionage as such. Few would doubt the need for criminal sanctions there. But the British constitution and system of administration contain many means whereby confidentiality can be ensured, and of calling to account those who breach it. Thus, ministerial responsibility, the Civil Service code of discipline, the law of confidence, and many other measures, both formal and informal, all have a role to play, and all were considered by Franks in 1972, and by the Government in 1988. On both occasions, the consensus seems to have been that criminal sanctions should apply only in respect of certain kinds of disclosures.

Three "yardsticks" are discernible in the Act (as they were in Franks, and even, to a limited extent, in the old section 2). These are directed at:

1. The type of information disclosed;

2. The position (or office) of the discloser;

3. The degree of harm resulting, or likely to result, from the disclosure. The "catch-all" nature of section 2, and, to some extent at least, the success (or otherwise) of the new Act, can be largely assessed by reference to these, given the declared aim of the Government "to narrow the scope of the present law so that the limited range of circumstances in which the unauthorised disclosure of official information needs to be criminal are clearly defined."38

Thus, for instance, Frederick Blake, the retired Prison Governor prosecuted for his "What Bywaters Told Me" article would not be guilty of any offence under the new Act nor would the Probate Registry clerk who "leaked" information concerning wills to the newspapers in 1932. In neither case would the information concerned be "protected" for the purposes of the 1989 Act. More contentiously, perhaps, it is at least arguable that Clive Ponting (who was, in any case acquitted under the old section 2) could not be successfully prosecuted by virtue of the requirement for 'harm', since the information disclosed by him, although "protected" (it related to defence) concerned events of two years earlier, and had ceased to be relevant operationally. ${ }^{39}$

36. S.11.

37. A concept somewhat whimsically captured in the American phrase "Government in The Sunshine".

38. Connd 408, para. 14.

39. The Ponting case is discussed further below, in connection with a "public interest" reference. 
Conversely, it might be argued that the scope of "protected" information has been narrowed too much. "Fiscal" information, and that relating to the currency (proposed by Franks for protection) is not specifically included, though some such information, insofar as it is given in confidence to other nations or international organisations, and relates to international relations, might be "protected" by section 6. Again, Franks proposed that information given to the Government in confidence by private individuals should be protected. ${ }^{40}$ The new Act makes no such provision. This is a regrettable omission, but not a surprising one. It was never the intention of the Government to legislate with respect to the protection of the privacy of the individual. It is notable, however, that Official Information legislation in many other countries contains just such a provision. The U.S.A. Freedom of Information Act, for instance, specifically excepts "personal and medical files, and similar files, the disclosure of which would institute a clearly unwarranted invasion of privacy", amongst other information, from the general requirement that information in the possession of Federal Agencies should be made available to the public. ${ }^{41}$ Similar provisions exist in Australian and Canadian official information legislation. The absence in the British constitution of any cogent alternative means of protecting confidential information of a personal character (unlike, say, cabinet and other governmental documents, in respect of which disciplinary procedures, conventional rules, and so on, apply) highlights this omission.

Doubtless, there will be those who feel that, whilst the old section 2 was badly drafted, and in need of reform, its "catch-all" nature was something of a strength, since it is not always possible to predict the harm that might result from a disclosure until it has actually occurred. Limiting the scope of the Act to specified categories of information and excluding others, therefore, is inherently risky! Accordingly, for some, a "catch-all" provision, with the safeguard of the Attorney-General's control over prosecutions, remains the "lesser of two evils". Much reliance, however, would thereby be placed on the independence of the Attorney-General. Indeed, Franks commented: "A catch-all provision is saved from absurdity only by the sparing exercise of the Attorney-General's discretion to prosecute." Yet ... "the very width of this discretion, and the inevitably selective way in which it is exercised give rise to considerable unease." ${ }^{, 42}$

To appreciate this point, we have to go back only as far as 1985, when the I.B.A. permitted the showing of a programme entitled "MI5's Official Secrets", despite

40. Cmnd. 5104, Vol. 1, paras. 192-206.

41. U.S. Code, Title 5, S552. (1966). This is exemption 6. The others involve information of the following kinds: 1 . National security; 2 . An agency's internal and personal affairs; 3 . Specified in a statute directing non-disclosure; 4 . Trade secrets or confidential commercial and financial information; 5. "Inter-agency" memoranda or letters which are not normally available in law by means of discovery; 6. Investigative records compiled by law enforcement agencies; 7 . Records of specified agencies, including The Federal Reserve Board, concerning financial and banking matters. 8. For some reason, "geological and geophysical information, including maps concerning wells".

42. Cmnd. 5104, Vol. 1, para. 88. 
advice that the programme involved a clear breach of section 2 of the Official Secrets Act based as it was in part on information provided by a former MI5 officer, Cathy Massiter. Doubtless not wishing to mount a further unpopular prosecution in the wake of the Ponting case, the Attorney-General, Sir Michael Havers, indicated that there would be no prosecution. On receiving this advice, the I.B.A. lifted the temporary ban it had placed on transmission, and the programme was shown on 8th March. Needless to say, Ms Massiter would be guilty under section 1 of the new Act. Furthermore, it seems highly unlikely that such revelations as those made by Ms Massiter would go unprosecuted. The narrowing down of the categories of information protected by the Act, and the particular provisions relating to security and intelligence members or ex-members, would seem to create a virtual 'mandate' for such prosecutions. Certainly, the resolve to mount them in future is likely to be far greater than it was in 1985 , with the Attorney-General being able to point to the very narrowness of the new Act as justification for its more-or-less automatic use. A "leaner" Act should prove both stronger and fitter for its purpose.

So much, then, for the narrowing of the categories of information, disclosure of which remains criminal under the new Act. What of the circumstances of disclosures, and in particular, the persons who are liable to prosecution? It is true that there was room for improvement. Again, the catch-all "flavour" could be discerned in the phrase "person holding office under His Majesty" in section 2. Its replacement by the more clearly defined categories of "Crown servants" and "government contractors" 43 is doubtless an improvement so far as clarity of draftsmanship is concerned. But will this new clarity, of itself, make any real difference in terms of actual prosecutions for unauthorised "primary" disclosures?

Paradoxically, this question may be tested by reference to a category of persons whose members, though clearly "holding office under His Majesty", have never been prosecuted: Ministers of the Crown. Despite some quite serious leaks of official information to the press, no Government Minister has ever been charged under section 2. Franks' explanation for this was that Ministers were largely "self-authorising"; as the political head of a Government department or Ministry, a senior Minister, at least, is subject to no higher authority in matters of disclosure, and therefore has to be regarded as vested with such authority himself. There is, of course, much in this argument. The assumption which is sometimes made, however, that Ministers are somehow privileged and therefore immune from prosecution, does not necessarily follow. Indeed, it has no basis whatever in Law. Thus, in the event that a Government Minister were to leak information protected under the 1989 Act, especially if it concerned matters which did not fall within the scope of his personal responsibility, one might reasonably expect a prosecution to occur, particularly since Ministers are actually specified in section 12. It is tempting to prognosticate, however, that, save for the most serious of 
leaks, amounting almost to espionage, Ministers will remain, in practice immune from prosecutions. Indeed, the lobby system of briefings would seem to demand it!

The scope of "protected" information, and of the categories of persons likely to be prosecuted, however, are not all that have been limited by the new Act. The failure of the Government to incorporate two possible general defences to charges of unlawful disclosure has been the subject of serious criticism, not least in the Press. It is to these that we must now turn.

\section{A "public interest" defence}

As has been established, the 1911 Act, in section 2, contained at least a form of "public interest" defence, albeit one which was severely limited in scope. Nowhere can this be seen to better advantage than in the case of Clive Ponting, the civil servant who in 1985 was prosecuted under section 2 for leaking ministerial memoranda to an M.P., Mr Tam Dalyell. The memoranda concerned the sinking of the Argentine cruiser General Belgrano, by a British submarine, on 2nd May 1982, at the height of the Falklands conflict. Ponting did not argue that the decision to sink the vessel had been wrong. It was his contention, that the leaked documents demonstrated the Government's intention to suppress the whole truth about the episode, and in so doing, mislead a Commons Select Committee which was investigating the matter. ${ }^{44}$ He leaked them to Dalyell because, though he was not a member of the Committee, he was a long-standing M.P. who had himself, Ponting felt, been deceived by Government Ministers when answering questions in the Commons.

At Ponting's trial, McCowan J directed the jury in the following terms. First, he said that section 2 had created a crime of basic intent only. It was not necessary for the prosecution to establish any particular intention on the accused's part, over and above the intention to communicate information to someone without authority. Certainly, it was not necessary to prove that his intention was to harm the interests of the State. Secondly, he told the jury that whilst section 2 had provided for a form of "public interest" defence, it should be interpreted narrowly, so that communication "to a person to whom it is in the interest of the State his duty to communicate it" meant a communication made, by a Civil Servant, in his official duty only. Finally, the judge suggested that "the interests of the state" were, for practical purposes, synonymous with Government policy. Despite this direction, the jury returned a verdict of "not guilty", and Ponting was duly acquitted.

The Government explained its reasons for rejecting a "public interest" defence in the White Paper. Whilst acknowledging that "some people who make unauthorised disclosures do so for what they themselves see as altruistic reasons", the Government felt that the "general model" in which motive is irrelevant to

44. Such conduct, if substantiated, would amount to a serious breach of convention: see, e.g., Erskine May's Parliamentany Practice, which makes it clear that any attempt or conspiracy to mislead a Parliamentary Committee amounts to a contempt of the House. 
criminal liability should be adhered to. There had been some feeling in Parliament, secondly, that the inclusion of such a defence would elevate "whistleblowers" and place them in some "special category", above thieves, murderers and the like. Thirdly, such a defence, it was argued, would detract from the clarity sought in the new Act. Accordingly, the Government felt that "any arguments as to the effects of disclosure on the public interest should take place within the context of the (proposed) damage tests where applicable." ${ }^{45}$

Unfortunately, each of these arguments can be challenged. First, the motives argument fails to take into consideration the possibility of an objective test of public interest. It fails, seemingly, to distinguish between cases like that of Ponting, on the one hand, and Sarah Tisdall on the other. Ms Tisdall, unlike Ponting, had been convicted and sentenced to prison, the first person to be so sentenced for fifteen years, when she leaked details concerning the disposition of Cruise missiles to the newspapers. The case is quite distinct from that of Clive Ponting, however, in that (a) the information she leaked did not suggest impropriety by Government, or any attempt to mislead Parliament, unlike Ponting's disclosures; and (b) she leaked it not to an M.P., but to a newspaper (The Guardian). Ms Tisdall's, arguably, was just the sort of case contemplated in the White Paper; Ponting's was not.

The provision of some statutory protection from reprisals for "whistleblowers" is by no means unknown. In the U.S.A., for instance, a civil servant who leaks information concerning fraud, waste, abuse and other types of wrongdoing in Government departments is given such protection. ${ }^{46}$

That such an objective test of public interest is incapable of precise definition is clearly not true. The concept of the public interest is a fairly commonplace one elsewhere in English law; in connection with discovery of documents, for instance, where the courts have grown well used to balancing degrees of harm to the public interest threatened by disclosures. ${ }^{47}$ The suggestion that considerations of the public interest can really best be dealt with in the context of the "damage test", too, must be closely examined. First, there is the suggestion that a "damaging" disclosure can never be in the public interest. The White Paper made this point clearly: "It cannot be acceptable that a person can lawfully disclose information which he knows may, for example, lead to loss of life simply because he conceives that he has a general reason of a public character for doing so." True: but not all disclosures need to be quite so damaging. Also, as already suggested, an objective test of "public interest" is perfectly feasible, and it is not necessarily a question of what the accused "conceives" to be his reasons for disclosing damaging information. Even the seeming paradox, that a disclosure could be "damaging" and yet in the public interest, is capable of being resolved. The Obscene

45. Cmnd. 408, para. 61.

46. The Civil Service Amendment Act ("whistleblower" Protection Act 1978, amended 1988, U.S. Code 200, S.20.).

47. See, e.g., Conmay v. Rimmer [1968] A.C. 910; D. v. N.S.P.C.C. [1977] A.C. 171, amongst others. 
Publications Act 1959, for instance, provides that a publication, though "obscene" (and therefore clearly "damaging", in that it "tends to corrupt and deprave"), may nevertheless be in the public good by reason of its being "in the interests of science, literature, art or learning or other subject of general concern." 48 It might be noted, too, that the test of "public interest" in obscene publications is left to the jury to apply. Another worrying aspect of the Government's claim arises from the fact that unless the phrase "public interest" actually appears in the Act, it is extremely unlikely that any jury will, in practice, be directed to the effect that it should form any part of their deliberations. It is hard to see, then, how argument as to the "public interest" would, in fact, take place at all.

The suggestion that a "Public Interest" defence would elevate those charged with Official Secrets offences simply falls down in the face of what we have already shown. Indeed, there seems to be every reason to treat offences involving "publications" of some sort - including disclosures of protected information quite differently from those, like murder, rape and theft, which do not. This is, not uncommonly, already the case. ${ }^{49}$ Thus, it is suggested that a "Public Interest" defence could have been successfully included in the Act if, indeed, it was the wish of the Government that considerations of the "Public Interest" should play some part in proceedings.

\section{A defence based on "prior publication".}

Save in limited form in section 6(5), concerning information communicated to another state or international organisation, which has been published with the authority of that state or organisation, no defence based on the fact that information has been previously published arises under the 1989 Act. Again, the Government considered such a defence, and gave its reasons for rejecting it, in the White Paper. These were basically twofold. First, confirmation of some story by a senior government official might prove considerably more damaging than a prior, unconfirmed publication. Secondly, information which has been previously published piecemeal in a number of sources, might prove damaging only when collated, and published as a single disclosure, e.g., a list of names and addresses which might prove useful to terrorists. ${ }^{50}$

These arguments have undeniable force. Also, as the Government pointed out, in a case where a publication is unlawful only if it causes harm, the offence would not be made out if no further harm is likely to result from a second disclosure.

48. Obscene Publications Act 1959, S.5, used effectively in the "Lady Chatterley's Lover" trial: $R$. v. Penguin Books Ltd. [1961] Crim. L.R. 176. Interestingly, and importantly, the judge in that case (Byrne J) ruled that the jury was only required to consider "public good" if it found that the book was obscene, and not otherwise.

49. In fact, "public interest" is a relevant consideration, or defence, in relation to a number of offences involving publications of one sort or another: these include, as well as obscene publications, libel and contempt of court (Contempt of Court Act 1981, s.5.) see, for a discussion on this, Yvonne Cripps: The Legal Implications of Disclosure in the Public Interest (1986).

50. Cmnd. 408 , paras. $62-64$. 
This would not apply, however, to a section 1 offence, which was of course the subject of the recent Spycatcher case, since the normal requirements for harm would not here apply. But the implication that a "prior publication" defence would be wholly novel must be scrutinised. In 1987, the Court of Appeal held that, once information had passed lawfully into the public domain, a further publication of such information was not an offence under section $2 .^{51}$ Insofar as a prior publication has not satisfied the requirement of harm, it would presumably be a "lawful" one under the Act. In 1988, the House of Lords took up the issue, at least indirectly. In A.G. v. Guardian Newspapers and Others, ${ }^{52}$ their Lordships held that an interlocutory injunction, restraining the appellants from publishing extracts of the book Spycatcher by the former MI5 officer, Peter Wright, should be lifted, and not replaced by a permanent injunction, on the grounds that all possible damage to the Crown's interests which could occur had, in fact, occurred as a consequence of "prior publication" of the material abroad.

It should be noted that the Government's argument - that most second publications would not be unlawful, since they would be unlikely to cause damage - would not apply to even "secondary" disclosures such as those involved in the Guardian case, under the 1989 Act. In connection with security and intelligence matters, even "secondary" disclosures do not have to cause damage as such. It is enough if they involve information of a "class" provided for in section 1(4)(b). Accordingly, if the Guardian case was to be heard when the new Act comes into force, a court would, presumably, be bound to make permanent an injunction restraining publication, despite the fact that publication all over the world has meant that no further harm to the public (or the Crown's) interests is possible!

So, whilst accepting the Government's argument that an absolute defence of prior publication might have proved impossible - even undesirable - one may nevertheless regret that "prior publication" will not be at least a relevant consideration when assessing the damage caused by any disclosure, even one involving security or intelligence matters, particularly when such a disclosure is a "secondary" one. It should have proved perfectly possible to retain strict liability, if that were felt necessary on the part of security officers and ex-security officers, whilst maintaining the essence of the Guardian decision, to the effect that, if all conceivable damage has been done, and can be demonstrably shown to have been done, it becomes somewhat pointless to 'muzzle' the Press by means of the threat of criminal sanctions.

\section{Conclusions}

Whilst the Government's justification for omitting the two defences discussed above is not wholly convincing, there is much that is desirable about the Act, and even those omissions must be considered in context. 
In general terms, the Government was right to seek to align Official Secrets' offences, so far as possible, with criminal offences generally. Thus, the inclusion of defences amounting to the absence of mens rea, and the requirement, in connection with most offences, of harm or likely harm, are commendable. With regard to the latter, too, the Government was right to reject Franks' system of conclusive Ministerial certification, correctly observing that such a system would, or would be seen to, place too much power in the hands of Ministers. Further, by rejecting such a scheme, the Government, once again, has aligned official secrets with other areas of recent development, such as the rules of public interest immunity in relation to discovery. That the mere unauthorised receipt of official information will no longer be criminal was a long overdue reform. The Act may well bring about some indirect benefits, too, in relation to public access to information. The provisions in section 4 , protecting information obtained by means of, or concerned with, interception of communications, could well be such that two benefits result. First, for a prosecution to be brought, it will presumably have to be established that such an interception had occurred, thus increasing public knowledge about such things. Secondly, such an interception will have to be a lawful one for a prosecution to succeed. Accordingly, unlawful interceptions may be brought to light. Under the present law, disclosure of any such interceptions, whether lawful or unlawful, is potentially criminal (subject to the "public interest" defence.)

In terms of the Government's objectives, then, the Act may be accounted a modest success. Its most notable failure, perhaps, is the apparent lack of regard for the confidentiality of private, personal information, which brings it out of line with Official Information legislation in most Western democracies, and with Franks' proposals. The arguments for rejecting Public Interest and Prior Publication defences are not wholly convincing, but their absence is likely to be offset somewhat by the fact that the requirements for harm (in most cases) will, hopefully, be argued in the normal way, by means of evidence, leading to judicial determination, and not settled by Ministerial determination.

On balance, then, except for those who regard a catch-all provision as the safer course, the new Act is, at the very least, likely to bring about a shift in the balance of interests, and to that extent, anyway, is an improvement on the old. 